OPEN ACCESS

Edited by:

Hyung-Sool Lee,

University of Waterloo, Canada

Reviewed by:

Daniele Cecconet,

University of Pavia, Italy

Haihan Zhang,

Xi'an University of Architecture

and Technology, China

*Correspondence:

Florian Einsiedl

f.einsiedl@tum.de

Michael Schloter

schloter@helmholtz-muenchen.de

Specialty section:

This article was submitted to

Microbiotechnology,

a section of the journal

Frontiers in Microbiology

Received: 02 November 2020

Accepted: 15 February 2021

Published: 04 March 2021

Citation:

Duffner C, Wunderlich A Schloter M, Schulz $S$ and Einsiedl $F$ (2021) Strategies to Overcome Intermediate Accumulation During in situ Nitrate Remediation in Groundwater by Hydrogenotrophic Denitrification

Front. Microbiol. 12:610437. doi: 10.3389/fmicb.2021.610437

\section{Strategies to Overcome Intermediate Accumulation During in situ Nitrate Remediation in Groundwater by Hydrogenotrophic Denitrification}

\author{
Clara Duffner ${ }^{1,2}$, Anja Wunderlich ${ }^{3}$, Michael Schloter ${ }^{1,2 *}$, Stefanie Schulz ${ }^{2}$ and \\ Florian Einsiedl/3*
}

${ }^{1}$ Chair of Soil Science, TUM School of Life Sciences Weihenstephan, Technical University of Munich, Freising, Germany, ${ }^{2}$ Research Unit Comparative Microbiome Analysis, Helmholtz Center Munich, Neuherberg, Germany, ${ }^{3}$ Chair of Hydrogeology, TUM Department of Civil, Geo and Environmental Engineering, Technical University of Munich, Munich, Germany

Bioremediation of polluted groundwater is one of the most difficult actions in environmental science. Nonetheless, the clean-up of nitrate polluted groundwater may become increasingly important as nitrate concentrations frequently exceed the EU drinking water limit of $50 \mathrm{mg} \mathrm{L}^{-1}$, largely due to intensification of agriculture and food production. Denitrifiers are natural catalysts that can reduce increasing nitrogen loading of aquatic ecosystems. Porous aquifers with high nitrate loading are largely electron donor limited and additionally, high dissolved oxygen concentrations are known to reduce the efficiency of denitrification. Therefore, denitrification lag times (time prior to commencement of microbial nitrate reduction) up to decades were determined for such groundwater systems. The stimulation of autotrophic denitrifiers by the injection of hydrogen into nitrate polluted regional groundwater systems may represent a promising remediation strategy for such environments. However, besides high costs other drawbacks, such as the transient or lasting accumulation of the cytotoxic intermediate nitrite or the formation of the potent greenhouse gas nitrous oxide, have been described. In this article, we detect causes of incomplete denitrification, which include environmental factors and physiological characteristics of the underlying bacteria and provide possible mitigation approaches.

Keywords: nitrate pollution, hydrogen-oxidizing denitrification, nitrite accumulation, bioremediation, abiotic nitrite reduction

\section{INTRODUCTION}

Increased amounts of reactive nitrogen $(\mathrm{Nr})$ and severe anthropogenic intervention in the global nitrogen cycle induce climatic change, cause biodiversity losses, and pose direct and indirect risks to human health (Fields, 2004; Galloway et al., 2008). In groundwater, the main $\mathrm{Nr}$ species is dissolved nitrate $\left(\mathrm{NO}_{3}{ }^{-}\right)$which leaches into the groundwater due to excessive use of chemical and organic fertilizers as well as leaking sewage (Zhu et al., 2019; Wild et al., 2020). The resulting $\mathrm{NO}_{3}{ }^{-}$pollution of groundwater has been a severe global environmental problem since the 1970s (Rivett et al., 2008). Because groundwater infiltrates into rivers, lakes, and subsequently into coastal areas these ecosystems suffer from $\mathrm{Nr}$-based eutrophication leading to toxic algal blooms and consequently 
anoxic “dead-zones" (Fields, 2004; Galloway et al., 2008) when natural attenuation processes fall short. A prominent example for coastal eutrophication is the Baltic Sea (Murray et al., 2019). The effect of eutrophication on urban lakes is also severe, as total$\mathrm{N}$ and $\mathrm{NO}_{3}{ }^{-}-\mathrm{N}$ are one of the primary factors determining the algal community composition (Zhang et al., 2021). Additionally, in many regions where groundwater is used as a drinking water resource, $\mathrm{NO}_{3}{ }^{-}$concentrations above the $\mathrm{WHO}$ recommended maximum of $50 \mathrm{mg} \mathrm{L}^{-1}$ require costly ex situ methods of $\mathrm{NO}_{3}{ }^{-}$ removal (Karanasios et al., 2010) or blending with less polluted water to ensure drinking water quality.

Denitrification, includes four main redox reactions from $\mathrm{NO}_{3}{ }^{-}$(redox state $+\mathrm{V}$ ), via nitrite $\left(\mathrm{NO}_{2}{ }^{-}\right)$, nitric oxide $(\mathrm{NO})$, and nitrous oxide $\left(\mathrm{N}_{2} \mathrm{O}\right)$ to atmospheric nitrogen $\left(\mathrm{N}_{2}\right.$, redox state 0 ), each catalyzed by a different metalloenzyme (Bothe et al., 2007). Since the first reduction step from $\mathrm{NO}_{3}{ }^{-}$to $\mathrm{NO}_{2}{ }^{-}$is also performed in other metabolic pathways and gaseous $\mathrm{N}_{2} \mathrm{O}$ gas can already leave the ecosystem, in a strict sense denitrification includes only $\mathrm{NO}_{2}^{-}$and $\mathrm{NO}$ respiration (Zumft, 1997). Nonetheless, because $\mathrm{NO}_{3}{ }^{-}$remediation aims at safely removing nitrogen from highly polluted aquatic systems, without releasing the greenhouse gas $\mathrm{N}_{2} \mathrm{O}$, in this work complete denitrification signifies the reduction of $\mathrm{NO}_{3}{ }^{-}$to $\mathrm{N}_{2}$. Only when the oxygen $\left(\mathrm{O}_{2}\right)$ concentration falls below $\sim 0.08-0.256 \mathrm{mg} \mathrm{L}^{-1}$ (Lycus et al., 2017) denitrification becomes energetically favorable and is initiated through precisely coordinated regulation. An exception are aerobic denitrifiers which may utilize $\mathrm{O}_{2}$ and $\mathrm{NO}_{3}{ }^{-}$simultaneously as electron acceptors, likely favorable in environments with fluctuating $\mathrm{O}_{2}$ concentrations and sufficient reduced carbon (Ji et al., 2015). Denitrification is known to occur in groundwater bodies (Korom, 1992). However, in some aquifers, none, or only little microbial available electron donors are present resulting in high dissolved $\mathrm{O}_{2}$ concentrations. Under these conditions, the intrinsic capacity for denitrification is low, whereby it will take years to decades (denitrification lag times) until the $\mathrm{O}_{2}$ is depleted and biotic $\mathrm{NO}_{3}{ }^{-}$reduction commences (Wassenaar, 1995; Wild et al., 2018).

Creating conditions favoring denitrification and supplementation with an electron donor presents a strategy for small-scale in situ $\mathrm{NO}_{3}{ }^{-}$remediation (Figure 1). Hydrogen $\left(\mathrm{H}_{2}\right)$ was proven to be a promising electron donor in multiple $\mathrm{NO}_{3}{ }^{-}$removal applications (Liessens et al., 1992; Chaplin et al., 2009; Karanasios et al., 2010). The risk of bio-clogging in aquifers due to $\mathrm{H}_{2}$ is lower compared to added dissolved carbon (Baveye et al., 1998) because the growth of autotrophic hydrogenotrophic denitrifiers is limited compared to heterotrophic denitrifiers in aquatic systems (Ergas and Reuss, 2001). Also, no byproducts which would require further purification are formed during the oxidation of $\mathrm{H}_{2}$ to water (Lee and Rittmann, 2002). The possibility of local off-grid $\mathrm{H}_{2}$ production using wind or solar energy (Ulleberg et al., 2010; Onwe et al., 2020) provides another advantage. Drinking water sources and critical natural resources could be protected locally without building up elaborate infrastructure for a cost-effective long-term operation. Another way that allows for "clean" remediation of numerous environmental contaminants in groundwater is provided by bio-electrochemical systems which may supply bacteria directly with electrons, as discussed in the review by Cecconet et al. (2020).

Several studies have attempted to stimulate hydrogenotrophic denitrification in closed systems (Haugen et al., 2002; Chaplin et al., 2009; Kumar et al., 2018; Duffner et al., 2021), columns, bioreactors (Liessens et al., 1992; Chang et al., 1999; Haugen et al., 2002; Lee and Rittmann, 2002; Schnobrich et al., 2007) as well as in situ (Chaplin et al., 2009). However, transient $\mathrm{NO}_{2}{ }^{-}$accumulation and/or incomplete denitrification has been reported in most of the batch and flow-through experiments. The $\mathrm{H}_{2}$ concentration was shown to be an influential factor determining complete denitrification because several flowthrough experiments were able to reach an effluent $\mathrm{NO}_{3}{ }^{-}$ concentration below $1 \mathrm{mg} \mathrm{NO}{ }_{3}^{-}-\mathrm{N} / \mathrm{L}$ and $\mathrm{NO}_{2}{ }^{-}$concentration below detection limit by increasing the $\mathrm{H}_{2}$ pressure (Haugen et al., 2002; Lee and Rittmann, 2002; Schnobrich et al., 2007). Other chemo-physical parameters which influence the denitrification efficiency are $\mathrm{pH}$ (Li et al., 2017), carbon dioxide $\left(\mathrm{CO}_{2}\right)$ availability, $\mathrm{NO}_{3}{ }^{-}$and $\mathrm{O}_{2}$ concentrations, as well as the water flow velocity (Ergas and Reuss, 2001; Haugen et al., 2002). The $\mathrm{pH}$ optimum of hydrogenotrophic denitrification is between 7.6 and 8.6 (Karanasios et al., 2010). Increased pH above 8.6 can inhibit the process (Lee and Rittmann, 2003) and generally $\mathrm{NO}_{2}{ }^{-}$accumulation increases with increasing $\mathrm{pH}$ (Lim et al., 2018). On the other side at $\mathrm{pH} 6.5$ or lower the maturation of the nitrous oxide reductase is inhibited resulting in significant $\mathrm{N}_{2} \mathrm{O}$ accumulation (Liu et al., 2014). $\mathrm{H}_{2}$ injection may strip $\mathrm{CO}_{2}$ from groundwater, altering the $\mathrm{CO}_{2}$ availability and as a result also the $\mathrm{pH}$. Thus, these parameters must be closely monitored. Additionally, the composition of the denitrifier community may determine whether denitrification is complete.

In the following sections, we will discuss the effects of $\mathrm{H}_{2}$ application on groundwater limited by atmospheric pressure and the influence of the hydrogenotrophic denitrifier community composition on the outcome of $\mathrm{NO}_{3}{ }^{-}$remediation. These factors have been already discussed in literature as major drivers of hydrogenotrophic denitrification. We discuss their impact on $\mathrm{NO}_{3}{ }^{-}$remediation in groundwater and how they can be controlled to foster complete denitrification. Additionally, we discuss combining the $\mathrm{H}_{2}$ amendment with the injection of $\mathrm{Fe}$ (II)-containing nano-sized minerals that stimulate abiotic $\mathrm{NO}_{2}{ }^{-}$reduction to $\mathrm{N}_{2} \mathrm{O}$ and could thereby prevent $\mathrm{NO}_{2}{ }^{-}$accumulation.

\section{FOSTERING COMPLETE DENITRIFICATION - HYDROGEN CONCENTRATION AS A MAJOR TRIGGER}

The dissolved $\mathrm{H}_{2}$ concentration in groundwater is the most important factor determining hydrogenotrophic denitrification efficiency at a neutral pH. Chang et al. (1999) observed that at a dissolved $\mathrm{H}_{2}$ concentration below $0.1 \mathrm{mg} \mathrm{L}^{-1}$ the nitrate reductase is inhibited while the nitrite reductase is inhibited already below $0.2 \mathrm{mg} \mathrm{L}^{-1}$. As the nitrite reductase responds 


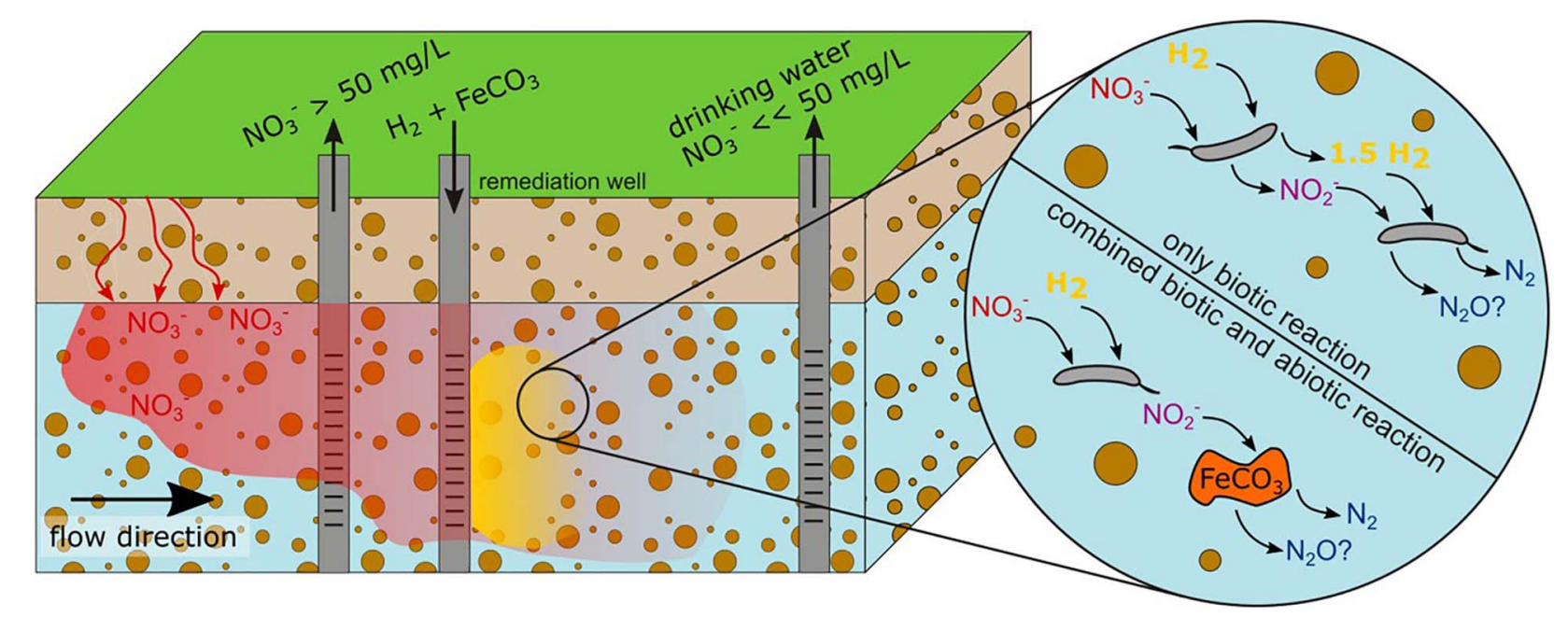

FIGURE 1 | Concept of local in situ $\mathrm{NO}_{3}{ }^{-}$remediation. The addition of $\mathrm{H}_{2}$ into an aquifer through a remediation well generates an anoxic $\mathrm{H}_{2}$-rich zone (yellow) where hydrogenotrophic denitrification is stimulated. Further downstream groundwater with $\mathrm{NO}_{3}^{-}$levels below the WHO recommended maximum of 50 mg $\mathrm{L}^{-1}$ could be obtained. Complementation with $\mathrm{Fe}(\mathrm{II})$-containing minerals (e.g., siderite $\mathrm{FeCO}_{3}$ ), injected in the anoxic, $\mathrm{H}_{2}$-rich zone, could foster complete denitrification by abiotic reduction of the intermediate $\mathrm{NO}_{2}^{-}$.

even more sensitive to low dissolved $\mathrm{H}_{2}$ concentrations than the nitrate reductase, $\mathrm{NO}_{2}{ }^{-}$accumulation in groundwater because of $\mathrm{H}_{2}$ limitation is likely. Optimal $\mathrm{H}_{2}$ concentrations for complete nitrogen removal are between 0.4 and $0.8 \mathrm{mg} \mathrm{L}^{-1} \mathrm{H}_{2}$ (Karanasios et al., 2011). Successful hydrogenotrophic denitrification with $\mathrm{H}_{2}$ concentration of $1.4 \mathrm{mg} \mathrm{\textrm {L } ^ { - 1 }}$, slightly below its maximum solubility of $1.6 \mathrm{mg} \mathrm{L}^{-1}\left(20^{\circ} \mathrm{C}\right.$, aqueous medium), have also been described in literature (Karanasios et al., 2010).

The dissolved $\mathrm{H}_{2}$ concentration in closed bottles with a headspace and a water phase can be determined easily as it is homogenous and proportional to the partial pressure of the headspace gas at a constant temperature according to Henry's law. However, in settings with a continuous water flow, such as in bioreactors or in an aquifer, it is difficult to determine the dissolved $\mathrm{H}_{2}$ concentrations. Most $\mathrm{H}_{2}$ is consumed directly inside the biofilm that is growing on the $\mathrm{H}_{2}$ releasing membrane and additionally local conditions change continuously due to the groundwater flow (Haugen et al., 2002; Lee and Rittmann, 2002). The required $\mathrm{H}_{2}$ gas supply pressure to achieve locally sufficiently high dissolved hydrogen concentrations for complete denitrification also differs depending on the $\mathrm{NO}_{3}{ }^{-}$ and $\mathrm{O}_{2}$ concentrations, as well as the water flow velocity (Haugen et al., 2002; Lee and Rittmann, 2002). Increasing the $\mathrm{H}_{2}$ gas supply pressure was the determining factor in several continuous flow reactor experiments to achieve complete $\mathrm{NO}_{3}{ }^{-}$ and $\mathrm{NO}_{2}{ }^{-}$reduction (Haugen et al., 2002; Lee and Rittmann, 2002; Schnobrich et al., 2007). To the best of our knowledge, in the only in situ experiment on hydrogenotrophic denitrification even an increase in the $\mathrm{H}_{2}$ lumen pressure from $1.68 \mathrm{~atm}$ to 2.36 atm could not resolve that only approximately half of the $\mathrm{NO}_{3}{ }^{-}$was reduced to $\mathrm{NO}_{2}{ }^{-}$, but not further to $\mathrm{N}_{2} \mathrm{O}$ or $\mathrm{N}_{2}$ (Chaplin et al., 2009). As the lightest molecule, the diffusion coefficient of $\mathrm{H}_{2}$ in water is large, making it more difficult to obtain sufficiently high dissolved $\mathrm{H}_{2}$ concentration in situ compared to a closed system such as a bioreactor. Its high diffusion and the bacterial biofilm formation decrease the $\mathrm{H}_{2}$ mobility and its zone of influence needed for efficient $\mathrm{NO}_{3}{ }^{-}$ removal. The denitrification activity is known to be largest in a biofilm of medium thickness and decreases when the biofilm further thickens (Chu and Wang, 2013). Thus, a large area of gas exchange accommodating as many bacteria as possible would be advantageous. A promising method to deliver gas over a large surface area are hollow-fiber membranes, e.g., made of gas-permeable silicon tubes (Ho et al., 2001).

In conclusion, it is important to determine the required local dissolved $\mathrm{H}_{2}$ concentration at the membrane water interface under consideration of the water flow velocity, as well as dissolved $\mathrm{O}_{2}$ and $\mathrm{NO}_{3}{ }^{-}$concentrations and the respective gas pressure needed to achieve this. Considering these difficulties of achieving sufficiently high dissolved $\mathrm{H}_{2}$ concentrations, initial in situ $\mathrm{NO}_{3}{ }^{-}$ remediation trials should focus on aquifers with high $\mathrm{NO}_{3}{ }^{-}$ pollution and innate low $\mathrm{O}_{2}$ concentrations so that only little $\mathrm{H}_{2}$ is utilized to react with the remaining $\mathrm{O}_{2}$.

\section{FOSTERING COMPLETE DENITRIFICATION - THE ROLE OF GENOMIC AND PHENOTYPIC PLASTICITY OF DENITRIFIERS}

Disparity between the genetic potential and the observed denitrification phenotypes, for example lacking $\mathrm{N}_{2} \mathrm{O}$ reduction despite the presence of a nitrous oxide reductase gene (nosZ), has been observed in several denitrifiers (Lycus et al., 2017). One possible explanation thereof is, that a functioning electron transfer coupled to proton translocation during denitrification (Figure 2A) requires several other 


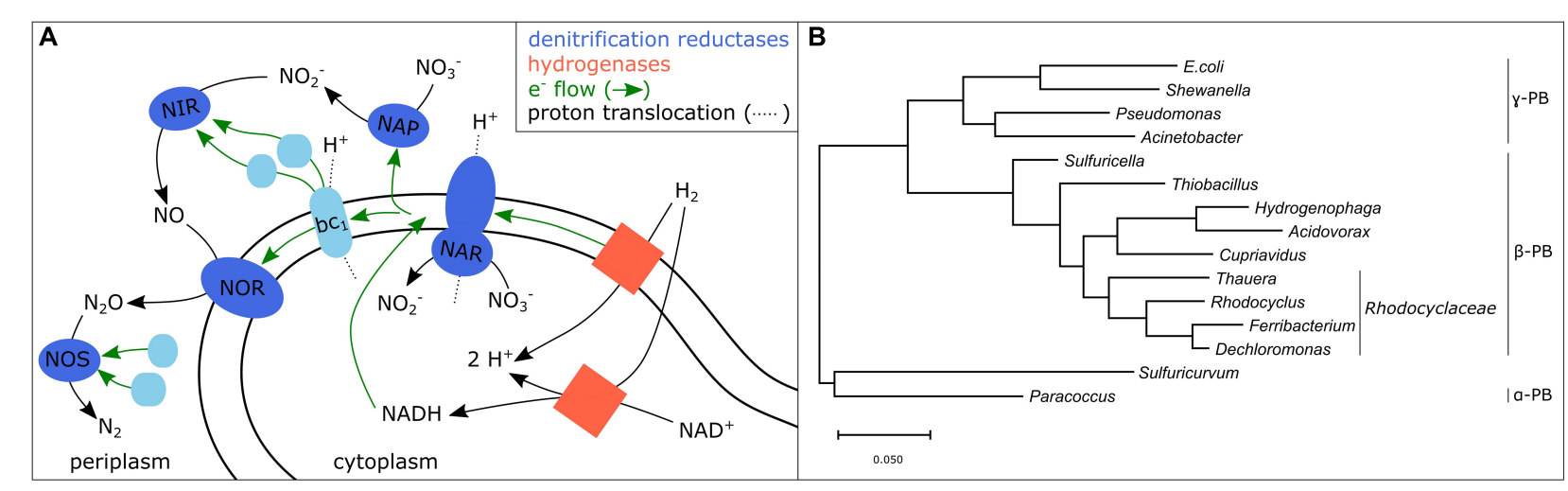

FIGURE 2 | (A) Scheme of a potential electron transport chain of hydrogenotrophic denitrifiers based on Bothe et al. (2007) and Matassa et al. (2015). Hydrogenases, membrane-bound or soluble, transfer electrons to ubiquinone (not depicted) which delivers electrons within the cell membrane to the membrane bound denitrification reductases NAR and NOR and to the cytochrome bc $c_{1}$ complex. The later delivers electrons via two other redox-active proteins to the periplasmic denitrification reductases NAP, NIR, and NOS. (B) Phylogenetic tree of genera which include autotrophic bacteria detected in hydrogenotrophic denitrifying systems (PB, Proteobacteria; Karanasios et al., 2010; Kumar et al., 2018; Wu et al., 2018).

proteins besides the reductases which ultimately influence the phenotypic outcome. These proteins include electron carriers, regulatory proteins, chaperonins, as well as proteins involved in metal processing, which together manage the maturation and finely coordinated regulation of the denitrification reductases (Philippot, 2002; Bothe et al., 2007). The genes encoding these proteins are arranged in gene clusters of which only few are conserved in all or most bacterial and archaeal genomes (Philippot, 2002). The disparities may have arisen due to several evolutionary drivers including horizontal gene transfer, convergent evolution of different structural types, as well as gene duplication and loss (Jones et al., 2008). The prediction of denitrification phenotypes based on genome sequences is in many cases still impossible, likely because of the divergence of gene cluster organization and the organization of those clusters in the genome. Additionally, the denitrification reductases compete for electrons from the electron transport chain (Albina et al., 2019). Some denitrification reductases are known to be stronger competitors (e.g., narG) than others (e.g., napA) (Gao et al., 2020) and the competition may even be additionally influenced by environmental factors such as $\mathrm{pH}$ (Albina et al., 2019).

Recent studies on heterotrophic pure cultures of denitrifiers (Bergaust et al., 2011; Liu et al., 2013; Lycus et al., 2017; Mania et al., 2020) revealed a vast phenotypic and genotypic diversity when investigating the difference in denitrification characteristics, termed "Denitrification Regulatory Phenotypes" (DRP). The phenotypic differences were visible in the $\mathrm{O}_{2}$ concentration at the onset of denitrification, the performed reduction steps, the electron flow rates to the individual denitrification reductases and resulting intermediate accumulation. Such differences were also observed in pure cultures of hydrogenotrophic denitrifiers (Vasiliadou et al., 2006). For example, while an Acinetobacter strain was accumulating 84.1\% of the initial $\mathrm{NO}_{3}{ }^{-}$as $\mathrm{NO}_{2}{ }^{-}$with $1.37 \mathrm{mg} \mathrm{L}^{-1}$ dissolved $\mathrm{H}_{2}$, strains belonging to the genera Acidovorax and Paracoccus did not show any $\mathrm{NO}_{2}{ }^{-}$accumulation (Vasiliadou et al., 2006).
Main taxa of the hydrogenotrophic denitrifier community, such as Acidovorax, Paracoccus, Acinetobacter, Pseudomonas, Paracoccus, Rhodocyclus, Hydrogenophaga, Sulfuritalea, and Dechloromonas, are well known from literature (Karanasios et al., 2010; Wu et al., 2018; Duffner et al., 2021) (Figure 2B). However, the results on DRPs show that phylogeny does not help to detect efficient hydrogenotrophic denitrifiers. Thus, the microbiological analysis must go beyond phylogeny and rather decipher the denitrification characteristics of hydrogenotrophic denitrifiers to identify intermediate accumulation and required parameters under which the former can be prevented. These required parameters include the previously stated such as minimal dissolved $\mathrm{H}_{2}$ concentration, maximum $\mathrm{O}_{2}$ concentration, dissolved $\mathrm{CO}_{2}$ availability, as well as the influence of biofilm formation and flow velocity. Once this data is available on widespread and efficient hydrogenotrophic denitrifiers, simple community analyses of site-specific hydrogenotrophic enrichment cultures could help to assess whether the native bacteria are able to perform complete denitrification and which conditions these bacteria require.

Generally, environmental conditions such as electron donor/electron acceptor interaction, which is highly affected by transversal dispersion in groundwater (Rolle et al., 2009), and dissolved carbon availability (Kraft et al., 2014) shape the bacterial community composition and the dominating metabolic pathways. In phylogenetically diverse microbial communities shifts in environmental conditions can change metabolic activities, while individual taxa do not have a notable influence. This is also true for denitrifying communities which have been described for example in bulk soil, where the degree of functional redundancy is high (Regan et al., 2017). Conversely, in less diverse bacterial communities, such as hydrogenotrophic denitrifiers (Karanasios et al., 2010; Duffner et al., 2021), the genotypic and phenotypic characteristics of individual taxa influence the dominating metabolic pathway more significantly, which makes the investigation of pure 
cultures even more relevant to understand hydrogenotrophic denitrification.

\section{FOSTERING COMPLETE DENITRIFICATION - COMBINING BIOTIC DENITRIFICATION WITH IRON-BASED ABIOTIC NITRITE REDUCTION}

Microbial catalyzed reduction of oxidized nitrogen species is not the only environmental process of $\mathrm{NO}_{3}{ }^{-}$remediation. Abiotic reduction of $\mathrm{NO}_{2}^{-}$by iron $\mathrm{Fe}(\mathrm{II})$, termed chemodenitrification, is also known to occur under environmentally relevant conditions (Jones et al., 2015; Buchwald et al., 2016; Grabb et al., 2017). The reduction of $\mathrm{NO}_{2}{ }^{-}$is catalyzed mainly by $\mathrm{Fe}$ (II) located on mineral surfaces while aqueous $\mathrm{Fe}(\mathrm{II})$ reacts much slower (Buchwald et al., 2016). Among the reactive $\mathrm{Fe}(\mathrm{II})$-containing minerals are siderite $\left(\mathrm{FeCO}_{3(s)}\right)$ (Rakshit et al., 2008), magnetite $\left(\mathrm{Fe}_{3} \mathrm{O}_{4}\right)$ (Dhakal et al., 2013; Margalef-Marti et al., 2020), pyrite $\left(\mathrm{FeS}_{2}\right)$, pyrrhotite $\left(\mathrm{Fe}_{(1-x)} \mathrm{S}\right)$, and biotite (Margalef-Marti et al., 2020). Fe(II)-containing minerals react rapidly with $\mathrm{NO}_{2}{ }^{-}$and the reaction may be much faster than abiotic $\mathrm{NO}_{3}{ }^{-}$reduction (Dhakal et al., 2013). This preference for $\mathrm{NO}_{2}{ }^{-}$over $\mathrm{NO}_{3}{ }^{-}$reduction makes $\mathrm{Fe}(\mathrm{II})$ containing minerals a beneficial additive to counteract the accumulation of $\mathrm{NO}_{2}{ }^{-}$. Supplementation with $\mathrm{Fe}(\mathrm{II})$-containing minerals alongside $\mathrm{H}_{2}$ injection thus presents a possible method to foster complete denitrification by sustaining $\mathrm{NO}_{2}{ }^{-}$and $\mathrm{NO}$ reduction and leaving more dissolved $\mathrm{H}_{2}$ to microbial denitrification.

An important factor contributing to the reactivity may be the mineral size of $\mathrm{Fe}$ (II)-containing minerals. Nano-sized but not macro-sized magnetite lead to complete $\mathrm{NO}_{3}{ }^{-}$reduction to $\mathrm{N}_{2}$ in an experiment by Margalef-Marti et al. (2020) due to greater surface area and $\mathrm{Fe}(\mathrm{II})$ availability. Additionally, nano-sized minerals have a wider range of distribution when injected into an aquifer. However, in order to prevent the exergonic oxidation of $\mathrm{Fe}$ (II) with dissolved $\mathrm{O}_{2}$ the nano-colloids should be injected directly with the $\mathrm{H}_{2}$ into the anaerobic plume in situ.

While reducing $\mathrm{NO}_{2}{ }^{-}$accumulation, the addition of $\mathrm{Fe}(\mathrm{II})$ containing minerals may increase accumulation of the gaseous intermediates $\mathrm{NO}$ and $\mathrm{N}_{2} \mathrm{O}$, which was demonstrated by isotope measurements and the calculated isotopic offsets between $\mathrm{NO}_{2}{ }^{-}$and $\mathrm{N}_{2} \mathrm{O}$. These showed that much of the $\mathrm{NO}_{2}{ }^{-}$consumed was not directly accounted for as $\mathrm{N}_{2} \mathrm{O}$ and likely accumulated as NO (Jones et al., 2015; MargalefMarti et al., 2020). The complementation with $\mathrm{H}_{2}$ injection to stimulate hydrogenotrophic denitrifiers is therefore necessary and the effect of $\mathrm{Fe}$ (II)-containing minerals on the physiological characteristics of the underlying bacteria must also be examined. In this regard, $\mathrm{Fe}$ (II)-containing minerals may also be used as electron donors by numerous autotrophic denitrifiers (Otero et al., 2009; Jones et al., 2015; Hernández-del Amo et al., 2018; Margalef-Marti et al., 2020). As a result the abiotic reduction of $\mathrm{NO}_{2}{ }^{-}$with $\mathrm{Fe}(\mathrm{II})$ may occur alongside microbial denitrification, the two processes are even interconnected (Melton et al., 2014) and may catalyze $\mathrm{NO}_{3}{ }^{-}$remediation. In the study of Margalef-Marti et al. (2020) magnetite nanoparticles alone rapidly reduced $\mathrm{NO}_{2}{ }^{-}$to $\mathrm{N}_{2} \mathrm{O}$ but the addition of a microbial inoculum stimulated complete reduction to $\mathrm{N}_{2}$. Lithoautotrophic $\mathrm{NO}_{3}{ }^{-}$-dependent pyrite oxidation has been detected as the predominant denitrification process in a carbon-limited aquifer (Schwientek et al., 2008; Otero et al., 2009), thus the responsible bacteria are likely widespread. Even though $\mathrm{NO}_{3}{ }^{-}$-dependent $\mathrm{Fe}(\mathrm{II})$ oxidation is an energetically favorable metabolism at neutral $\mathrm{pH}$, most $\mathrm{NO}_{3}{ }^{-}$reducing $\mathrm{Fe}(\mathrm{II})$-oxidizing bacteria require an additional electron donor or organic carbon for growth (Weber et al., 2006; Melton et al., 2014). These findings indicate that apart from the abiotic reduction, introducing a second electron donor to stimulate denitrification potentially increases the bacterial diversity making the enriched denitrifying community likely more resilient (Girvan et al., 2005).

Even though the injection of nano-sized particles to contaminated sites is already applied in some countries, concerns remain, including unknown long-term effects, transformation and ecotoxicity (Crane and Scott, 2012). For example, adverse effects of nano-sized iron on the biomass and activity of soil microbial communities under stress have been determined (Anza et al., 2019). Additionally, nanosized particles or reaction products may react rapidly with sediment leading to clogging of the reactive zone and forcing the groundwater to bypass (Strutz et al., 2016). Therefore, before such nano-sized particles can be applied in situ, their long-term behavior in the investigated aquifer type must be determined.

\section{SUMMARY AND OUTLOOK}

Fostering complete hydrogenotrophic denitrification in situ can only be achieved by combining multiple approaches. First, it is important to determine and estimate a set of aquifer parameters in $\mathrm{NO}_{3}{ }^{-}$polluted groundwater to decide whether $\mathrm{NO}_{3}{ }^{-}$remediation by $\mathrm{H}_{2}$ injection is feasible under the given hydrogeological conditions. These parameters include $\mathrm{pH}$, organic and inorganic carbon contents, dissolved $\mathrm{O}_{2}$ concentrations and $\mathrm{NO}_{3}{ }^{-}$concentrations, the groundwater flow velocity, potential biofilm formation, and the transversal dispersion. For example, when treating groundwater, $\mathrm{pH}$ shifts below 6.5 or above 8 may lead to an accumulation of $\mathrm{NO}_{2}{ }^{-}$and make the $\mathrm{NO}_{3}{ }^{-}$polluted aquifer unsuitable for bioremediation. Therefore, clean-up strategies of $\mathrm{NO}_{3}{ }^{-}$polluted aquifers may only be sustainable in groundwater with sufficient inorganic carbon which is able to buffer $\mathrm{pH}$ changes. Second, hydrogen-enhanced denitrification requires an effective $\mathrm{H}_{2}$ transfer into the aquifer which must be adapted considering the previously stated parameters to ensure locally sufficiently high $\mathrm{H}_{2}$ concentrations. Third, the denitrification phenotypes of dominant hydrogenotrophic denitrifiers must be understood 
in depth. Hence the native bacterial community in the aquifer can be screened for complete hydrogenotrophic denitrifiers with little intermediate accumulation by amplicon sequencing approaches. Thus, one can determine whether the community is beneficial for complete denitrification or whether bacterial augmentation is necessary. Since these bacteria are generally low abundant in oxic groundwater, it is advised to enrich hydrogenotrophic denitrifiers under selective conditions before the screening.

Being a sequential process, it is difficult to avoid transient $\mathrm{NO}_{2}{ }^{-}$accumulation during denitrification completely, especially in situ. When almost all dissolved $\mathrm{O}_{2}$ is reduced in groundwater an amendment with $\mathrm{Fe}(\mathrm{II})$-containing minerals could thus aid the denitrifiers if periods of $\mathrm{NO}_{2}{ }^{-}$ accumulation occur and could potentially diversify the denitrifying community by providing an additional electron donor. Our analysis shows that remediation strategies of $\mathrm{NO}_{3}{ }^{-}$polluted groundwater may be feasible in inorganic rich shallow groundwater systems that are characterized by low $\mathrm{O}_{2}$ concentrations, low organic carbon concentrations, but high $\mathrm{NO}_{3}-$ concentrations.

\section{REFERENCES}

Albina, P., Durban, N., Bertron, A., Albrecht, A., Robinet, J. C., and Erable, B. (2019). Influence of hydrogen electron donor, alkaline $\mathrm{pH}$, and high nitrate concentrations on microbial denitrification: a review. Int. J. Mol. Sci. 20:5163. doi: 10.3390/ijms20205163

Anza, M., Salazar, O., Epelde, L., Alkorta, I., and Garbisu, C. (2019). The application of nanoscale zero-valent iron promotes soil remediation while negatively affecting soil microbial biomass and activity. Front. Environ. Sci. 7:19. doi: 10.3389/fenvs.2019.00019

Baveye, P., Vandevivere, P., Hoyle, B. L., DeLeo, P. C., and de Lozada, D. S. (1998). Environmental impact and mechanisms of the biological clogging of saturated soils and aquifer materials. Crit. Rev.Environ. Sci. Technol. 28, 123-191. doi: 10.1080/10643389891254197

Bergaust, L., Bakken, L. R., and Frostegård, Å (2011). Denitrification regulatory phenotype, a new term for the characterization of denitrifying bacteria. Biochem. Soc. Trans. 39, 207-212. doi: 10.1042/bst0390207

Bothe, H., Ferguson, S., and Newton, W. (2007). Biology of the Nitrogen Cycle. Amsterdam: Elsevier Science.

Buchwald, C., Grabb, K., Hansel, C. M., and Wankel, S. D. (2016). Constraining the role of iron in environmental nitrogen transformations: dual stable isotope systematics of abiotic NO2- reduction by $\mathrm{Fe}(\mathrm{II})$ and its production of N2O. Geochim. Cosmochim. Acta 186, 1-12. doi: 10.1016/j.gca.2016. 04.041

Cecconet, D., Sabba, F., Devecseri, M., Callegari, A., and Capodaglio, A. G. (2020). In situ groundwater remediation with bioelectrochemical systems: a critical review and future perspectives. Environ. Int. 137:105550. doi: 10.1016/j.envint. 2020.105550

Chang, C. C., Tseng, S. K., and Huang, H. K. (1999). Hydrogenotrophic denitrification with immobilized Alcaligenes eutrophus for drinking water treatment. Bioresour. Technol. 69, 53-58. doi: 10.1016/s0960-8524(98)00168-0

Chaplin, B. P., Schnobrich, M. R., Widdowson, M., Semmens, M. J., and Novak, P. J. (2009). Stimulating in situ hydrogenotrophic denitrification with membrane-delivered hydrogen under passive and pumped groundwater conditions. J. Environ. Eng. 135, 666-676. doi: 10.1061/(asce)ee.1943-7870.000 0021

Chu, L., and Wang, J. (2013). Denitrification performance and biofilm characteristics using biodegradable polymers PCL as carriers and carbon source. Chemosphere 91, 1310-1316. doi: 10.1016/j.chemosphere.2013.02.064

\section{DATA AVAILABILITY STATEMENT}

The original contributions presented in the study are included in the article/supplementary material, further inquiries can be directed to the corresponding author/s.

\section{AUTHOR CONTRIBUTIONS}

FE and MS developed the project idea and secured necessary funding to support the work of this manuscript. CD conceived and prepared the first draft of this manuscript. AW, SS, FE, and MS critically reviewed the draft. All authors contributed to the article and approved the submitted version.

\section{FUNDING}

CD received funding by Deutsche Forschungsgemeinschaft (DFG) through TUM International Graduate School of Science and Engineering (IGSSE), GSC 81.

Crane, R. A., and Scott, T. B. (2012). Nanoscale zero-valent iron: future prospects for an emerging water treatment technology. J. Hazard. Mater. 21, 112-125. doi: 10.1016/j.jhazmat.2011.11.073

Dhakal, P., Matocha, C. J., Huggins, F. E., and Vandiviere, M. M. (2013). Nitrite reactivity with magnetite. Environ. Sci. Technol. 47, 6206-6213. doi: 10.1021/ es304011w

Duffner, C., Holzapfel, S., Wunderlich, A., Einsiedl, F., Schloter, M., and Schulz, S. (2021). Dechloromonas and close relatives prevail hydrogenotrophic denitrification in stimulated microcosms with oxic aquifer material. FEMS Microbiol. Ecol. Epub ahead of print

Ergas, S. J., and Reuss, A. F. (2001). Hydrogenotrophic denitrification of drinking water using a hollow fibre membrane bioreactor. J. Water Supply Res. Technol. Aqua 50, 161-171. doi: 10.2166/aqua.2001.0015

Fields, S. (2004). Global nitrogen: cycling out of control. Environ. Health Perspect. $112,556-563$.

Galloway, J. N., Townsend, A. R., Erisman, J. W., Bekunda, M., Cai, Z., Freney, J. R., et al. (2008). Transformation of the nitrogen cycle: recent trends, questions, and potential solutions. Science 320, 889-892. doi: 10.1126/science.1136674

Gao, Y., Mania, D., Mousavi, S., Lycus, P., Arntzen, M., Woliy, K., et al. (2020). Competition for electrons favors N2O reduction in denitrifying Bradyrhizobium isolates. bioRxiv [Preprint]

Girvan, M. S., Campbell, C. D., Killham, K., Prosser, J. I., and Glover, L. A. (2005). Bacterial diversity promotes community stability and functional resilience after perturbation. Environ. Microbiol. 7, 301-313. doi: 10.1111/j.1462-2920.2005. 00695.x

Grabb, K. C., Buchwald, C., Hansel, C. M., and Wankel, S. D. (2017). A dual nitrite isotopic investigation of chemodenitrification by mineral-associated $\mathrm{Fe}(\mathrm{II})$ and its production of nitrous oxide. Geochim. Cosmochim. Acta 196, 388-402. doi: 10.1016/j.gca.2016.10.026

Haugen, K. S., Semmens, M. J., and Novak, P. J. (2002). A novel in situ technology for the treatment of nitrate contaminated groundwater. Water Res. 36, 34973506. doi: 10.1016/s0043-1354(02)00043-x

Hernández-del Amo, E., Menció, A., Gich, F., Mas-Pla, J., and Bañeras, L. (2018). Isotope and microbiome data provide complementary information to identify natural nitrate attenuation processes in groundwater. Sci. Total Environ. 61, 579-591. doi: 10.1016/j.scitotenv.2017.09.018

Ho, C. M., Tseng, S. K., and Chang, Y. J. (2001). Autotrophic denitrification via a novel membrane-attached biofilm reactor. Lett. Appl. Microbiol. 33, 201-205. doi: 10.1046/j.1472-765x.2001.00984.x 
Ji, B., Yang, K., Zhu, L., Jiang, Y., Wang, H., Zhou, J., et al. (2015). Aerobic denitrification: a review of important advances of the last 30 years. Biotechnol. Bioprocess Eng. 20, 643-651. doi: 10.1007/s12257-015-0009-0

Jones, C. M., Stres, B., Rosenquist, M., and Hallin, S. (2008). Phylogenetic analysis of nitrite, nitric oxide, and nitrous oxide respiratory enzymes reveal a complex evolutionary history for denitrification. Mol. Biol. Evol. 25, 1955-1966. doi: 10.1093/molbev/msn146

Jones, L. C., Peters, B., Lezama Pacheco, J. S., Casciotti, K. L., and Fendorf, S. (2015). Stable isotopes and iron oxide mineral products as markers of chemodenitrification. Environ. Sci. Technol. 49, 3444-3452. doi: 10.1021/ es504862x

Karanasios, K. A., Michailides, M. K., Vasiliadou, I. A., Pavlou, S., and Vayenas, D. V. (2011). Potable water hydrogenotrophic denitrification in packed-bed bioreactors coupled with a solar-electrolysis hydrogen production system. Desalination Water Treat. 33, 86-96. doi: 10.5004/dwt.2011.2614

Karanasios, K. A., Vasiliadou, I. A., Pavlou, S., and Vayenas, D. V. (2010). Hydrogenotrophic denitrification of potable water: a review. J. Hazard. Mater. 180, 20-37. doi: 10.1016/j.jhazmat.2010.04.090

Korom, S. F. (1992). Natural denitrification in the saturated zone: a review. Water Resour. Res. 28, 1657-1668. doi: 10.1029/92wr00252

Kraft, B., Tegetmeyer, H. E., Sharma, R., Klotz, M. G., Ferdelman, T. G., Hettich, R. L., et al. (2014). The environmental controls that govern the end product of bacterial nitrate respiration. Science 345, 676-679. doi: 10.1126/science. 1254070

Kumar, S., Herrmann, M., Blohm, A., Hilke, I., Frosch, T., Trumbore, S. E., et al. (2018). Thiosulfate- and hydrogen-driven autotrophic denitrification by a microbial consortium enriched from groundwater of an oligotrophic limestone aquifer. FEMS Microbiol. Ecol. 94:fiy141.

Lee, K. C., and Rittmann, B. E. (2002). Applying a novel autohydrogenotrophic hollow-fiber membrane biofilm reactor for denitrification of drinking water. Water Res. 36, 2040-2052. doi: 10.1016/s0043-1354(01)00425-0

Lee, K. C., and Rittmann, B. E. (2003). Effects of $\mathrm{pH}$ and precipitation on autohydrogenotrophic denitrification using the hollow-fiber membranebiofilm reactor. Water Res. 37, 1551-1556. doi: 10.1016/s0043-1354(02) 00519-5

Li, P., Wang, Y., Zuo, J., Wang, R., Zhao, J., and Du, Y. (2017). Nitrogen removal and N2O accumulation during hydrogenotrophic denitrification: influence of environmental factors and microbial community characteristics. Environ. Sci. Technol. 51, 870-879. doi: 10.1021/acs.est.6b00071

Liessens, J., Vanbrabant, J., De Vos, P., Kersters, K., and Verstraete, W. (1992). Mixed culture hydrogenotrophic nitrate reduction in drinking water. Micro. Ecol. 24, 271-290. doi: 10.1007/bf00167786

Lim, N. Y. N., Frostegård, Å, and Bakken, L. R. (2018). Nitrite kinetics during anoxia: the role of abiotic reactions versus microbial reduction. Soil Biol. Biochem. 119, 203-209. doi: 10.1016/j.soilbio.2018.01.006

Liu, B., Frostegård, Å, and Bakken, L. R. (2014). Impaired reduction of N2O to N2 in acid soils is due to a posttranscriptional interference with the expression of nosZ. mBio 5, e01383-14.

Liu, B., Mao, Y., Bergaust, L., Bakken, L. R., and Frostegård, Å (2013). Strains in the genus Thauera exhibit remarkably different denitrification regulatory phenotypes. Environ. Microbiol. 15, 2816-2828.

Lycus, P., Lovise Bøthun, K., Bergaust, L., Peele Shapleigh, J., Reier Bakken, L., and Frostegård, A (2017). Phenotypic and genotypic richness of denitrifiers revealed by a novel isolation strategy. ISME J. 11, 2219-2232. doi: 10.1038/ismej.2017.82

Mania, D., Woliy, K., Degefu, T., and Frostegård, Å (2020). A common mechanism for efficient $\mathrm{N} 2 \mathrm{O}$ reduction in diverse isolates of nodule-forming bradyrhizobia. Environ. Microbiol. 22, 17-31.

Margalef-Marti, R., Carrey, R., Benito, J. A., Marti, V., Soler, A., and Otero, N. (2020). Nitrate and nitrite reduction by ferrous iron minerals in polluted groundwater: isotopic characterization of batch experiments. Chem. Geol. 548:119691. doi: 10.1016/j.chemgeo.2020.119691

Matassa, S., Boon, N., and Verstraete, W. (2015). Resource recovery from used water: The manufacturing abilities of hydrogen-oxidizing bacteria. Water Res. 68, 467-478. doi: 10.1016/j.watres.2014.10.028

Melton, E. D., Swanner, E. D., Behrens, S., Schmidt, C., and Kappler, A. (2014). The interplay of microbially mediated and abiotic reactions in the biogeochemical Fe cycle. Nat. Rev. Microbiol. 12, 797-808. doi: 10.1038/nrmicro3347
Murray, C. J., Müller-Karulis, B., Carstensen, J., Conley, D. J., Gustafsson, B. G., and Andersen, J. H. (2019). Past, present and future eutrophication status of the Baltic Sea. Front. Mar. Sci. 6:2. doi: 10.3389/fmars.2019.00002

Onwe, C. A., Rodley, D., and Reynolds, S. (2020). Modelling and simulation tool for off-grid PV-hydrogen energy system. Int. J. Sustain. Energy 39, 1-20. doi: 10.1080/14786451.2019.1617711

Otero, N., Torrentó, C., Soler, A., Menció, A., and Mas-Pla, J. (2009). Monitoring groundwater nitrate attenuation in a regional system coupling hydrogeology with multi-isotopic methods: the case of Plana de Vic. (Osona, Spain). Agric. Ecosyst. Environ. 133, 103-113. doi: 10.1016/j.agee.2009. 05.007

Philippot, L. (2002). Denitrifying genes in bacterial and archaeal genomes. Biochim. Biophys. Acta 1577, 355-376. doi: 10.1016/s0167-4781(02)00 420-7

Rakshit, S., Matocha, C. J., and Coyne, M. S. (2008). Nitrite reduction by siderite. Soil Sci. Soc. Am. J. 72, 1070-1077. doi: 10.2136/sssaj2007. 0296

Regan, K., Stempfhuber, B., Schloter, M., Rasche, F., Prati, D., Philippot, L., et al. (2017). Spatial and temporal dynamics of nitrogen fixing, nitrifying and denitrifying microbes in an unfertilized grassland soil. Soil. Biol. Biochem. 109, 214-226. doi: 10.1016/j.soilbio.2016.11.011

Rivett, M. O., Buss, S. R., Morgan, P., Smith, J. W. N., and Bemment, C. D. (2008). Nitrate attenuation in groundwater: a review of biogeochemical controlling processes. Water Res. 42, 4215-4232. doi: 10.1016/j.watres.2008. 07.020

Rolle, M., Eberhardt, C., Chiogna, G., Cirpka, O. A., and Grathwohl, P. (2009). Enhancement of dilution and transverse reactive mixing in porous media: experiments and model-based interpretation. J. Contam. Hydrol. 110, 130-142. doi: 10.1016/j.jconhyd.2009.10.003

Schnobrich, M. R., Chaplin, B. P., Semmens, M. J., and Novak, P. J. (2007). Stimulating hydrogenotrophic denitrification in simulated groundwater containing high dissolved oxygen and nitrate concentrations. Water Res. 41, 1869-1876. doi: 10.1016/j.watres.2007.01.044

Schwientek, M., Einsiedl, F., Stichler, W., Stögbauer, A., Strauss, H., and Maloszewski, P. (2008). Evidence for denitrification regulated by pyrite oxidation in a heterogeneous porous groundwater system. Chem. Geol. 255, 60-67. doi: 10.1016/j.chemgeo.2008.06.005

Strutz, T. J., Hornbruch, G., Dahmke, A., and Köber, R. (2016). Influence of permeability on nanoscale zero-valent iron particle transport in saturated homogeneous and heterogeneous porous media. Environ. Sci. Pollut. Res. 23, 17200-17209. doi: 10.1007/s11356-016-6814-y

Ulleberg, $\varnothing$, Nakken, T., and Eté, A. (2010). The wind/hydrogen demonstration system at Utsira in Norway: evaluation of system performance using operational data and updated hydrogen energy system modeling tools. Int. J. Hydrogen Energy 35, 1841-1852. doi: 10.1016/j.ijhydene.2009. 10.077

Vasiliadou, I. A., Siozios, S., Papadas, I. T., Bourtzis, K., Pavlou, S., and Vayenas, D. V. (2006). Kinetics of pure cultures of hydrogen-oxidizing denitrifying bacteria and modeling of the interactions among them in mixed cultures. Biotechnol. Bioeng. 95, 513-525. doi: 10.1002/bit.21031

Wassenaar, L. I. (1995). Evaluation of the origin and fate of nitrate in the abbotsford aquifer using the isotopes of $15 \mathrm{~N}$ and18O in NO3-. Appl. Geochem. 10, 391-405. doi: 10.1016/0883-2927(95) 00013-a

Weber, K. A., Achenbach, L. A., and Coates, J. D. (2006). Microorganisms pumping iron: anaerobic microbial iron oxidation and reduction. Nat. Rev. Microbiol. 4, 752-764. doi: 10.1038/nrmicro1490

Wild, L., Mayer, B., and Einsiedl, F. (2018). Decadal delays in groundwater recovery from nitrate contamination caused by low $\mathrm{O} 2$ reduction rates. Water Resour. Res. 54, 9996-10012. doi: 10.1029/2018wr 023396

Wild, L. M., Rein, A., and Einsiedl, F. (2020). Monte Carlo simulations as a decision support to interpret $\delta 15 \mathrm{~N}$ values of nitrate in groundwater. Groundwater 58 , 571-582. doi: 10.1111/gwat.12936

Wu, J., Yin, Y., and Wang, J. (2018). Hydrogen-based membrane biofilm reactors for nitrate removal from water and wastewater. Int. J. Hydrogen Energy 43, 1-15. doi: 10.1016/j.ijhydene.2017.10.178 
Zhang, H., Zong, R., He, H., Liu, K., Yan, M., Miao, Y., et al. (2021). Biogeographic distribution patterns of algal community in different urban lakes in China: insights into the dynamics and co-existence. J. Environ. Sci. 100, 216-227. doi: 10.1016/j.jes.2020.07.024

Zhu, A., Chen, J., Gao, L., Shimizu, Y., Liang, D., Yi, M., et al. (2019). Combined microbial and isotopic signature approach to identify nitrate sources and transformation processes in groundwater. Chemosphere 228, 721-734. doi: 10.1016/j.chemosphere.2019.04.163

Zumft, W. G. (1997). Cell biology and molecular basis of denitrification. Microbiol. Mol. Biol. Rev. 61, 533-616. doi: 10.1128/.61.4.533-616. 1997
Conflict of Interest: The authors declare that the research was conducted in the absence of any commercial or financial relationships that could be construed as a potential conflict of interest.

Copyright (c) 2021 Duffner, Wunderlich, Schloter, Schulz and Einsiedl. This is an open-access article distributed under the terms of the Creative Commons Attribution License (CC BY). The use, distribution or reproduction in other forums is permitted, provided the original author(s) and the copyright owner(s) are credited and that the original publication in this journal is cited, in accordance with accepted academic practice. No use, distribution or reproduction is permitted which does not comply with these terms. 